\title{
Kernos
}

Revue internationale et pluridisciplinaire de religion grecque antique

29 | 2016

Varia

\section{Religious Associations in the Post-Classical Polis}

\section{Stella Skaltsa}

\section{OpenEdition \\ Journals}

\section{Electronic version}

URL: http://journals.openedition.org/kernos/2427

DOI: $10.4000 /$ kernos.2427

ISSN: 2034-7871

\section{Publisher}

Centre international d'étude de la religion grecque antique

\section{Printed version}

Date of publication: 1 October 2016

Number of pages: 435-439

ISSN: 0776-3824

Electronic reference

Stella Skaltsa, "Religious Associations in the Post-Classical Polis », Kernos [Online], 29 | 2016, Online since 01 October 2016, connection on 17 November 2020. URL : http://journals.openedition.org/ kernos/2427 ; DOI : https://doi.org/10.4000/kernos.2427

This text was automatically generated on 17 November 2020 .

Kernos 


\title{
Religious Associations in the Post- Classical Polis
}

\author{
Stella Skaltsa
}

\section{REFERENCES}

Julietta STEINHAUER, Religious Associations in the Post-Classical Polis, Stuttgart, Franz Steiner Verlag, 2014. 1 vol. $17 \times 24 \mathrm{~cm}, 189$ p. (Postdamer Altertumswissenschaftliche Beiträge, 50). ISBN : 978-3-515-10646-7.

1 The book, stemming from Steinhauer's PhD thesis undertaken at the University of St Andrews, constitutes a timely contribution to a much broader topic, namely ancient associations in the Eastern Mediterranean. Indeed, this is a promising field of investigation that has lately attracted unprecedented attention on both sides of the Atlantic (most notably, the De Gruyter series on Greco-Roman Associations as well as the forthcoming online database on Ancient Associations by the Copenhagen Associations Project). ${ }^{1}$ Steinhauer (henceforth S.) turns her attention to religious associations in particular. Drawing upon epigraphic as well as archaeological evidence, she sets out to investigate the nature of this "novel religious form" (p.15) and its development in the Aegean during the Hellenistic and Roman periods. In tune with current scholarship, which views religion as "a medium for the creation of new structures" (p. 22), S. approaches religious associations as social entities (p. 16). As interesting as this approach may be, given that it shifts focus away from ritual and religious practices, one would have nevertheless expected a clear definition of what differentiates a religious association from a traditional religious group or a temporary group of worshippers (p. 16).

2 Religious associations, unlike pre-existing social, political or ethnic entities, provided the social and institutional framework for people of different ethnic, social or cultural backgrounds, to come together for the worship of a common deity. S. proposes to concentrate mostly on non-traditional or so-called 'new' deities, that is to say foreign 
gods introduced in the Aegean before or around the Hellenistic period; they are qualified as 'new' since they are not mentioned in Homer and Hesiod (p. 71). More specifically, the emphasis is placed on associations of Egyptian and Oriental deities, Jewish groups, as well as groups centered around the cult of Bendis, Sabazios, the Mother of Gods, and among the traditional gods, Dionysos. Associations of eranistai (eranoi), though very briefly introduced (p.18, n. 10), do not form a main point of discussion in the case of Athens, and are seldom mentioned otherwise. In this respect, S. breaks with a long scholarly tradition that goes back to Paul Foucart, the first scholar to have dedicated a monograph to this same topic - religious associations - which is still useful but unfortunately omitted from the bibliography. ${ }^{2}$

The book consists of seven chapters, including an introduction and conclusion. Unlike some recent studies that focus on associations in a single city, S. adopts both a casestudy approach (chapters 2 and 3 treat Athens and Delos respectively) and a thematic approach (chapters 4,5 and 6) which engages with a rich epigraphic record that spans at least five centuries and originates from various cities. In this respect, S. provides a comparative study of associations, without, however, offering an exhaustive or a systematic collection of the available evidence.

In chapter 2, discussing 127 inscriptions attesting to religious associations in Athens and its port Piraeus from the second half of the $4^{\text {th }} \mathrm{c}$. BC to the $3^{\text {rd }} \mathrm{c}$. AD, S. presents a diachronic overview: associations in Athens usually outnumber those in Piraeus (in the $4^{\text {th }} \mathrm{c} . \mathrm{BC}$, there are 16 associations attested in Athens compared to 7 in Piraeus; $3^{\text {rd }} \mathrm{C} . \mathrm{BC}$ : 26 in Athens vs 12 in Piraeus; etc.). Despite the greater visibility of associations in Athens, the epigraphic record from Piraeus, a multiethnic port, displays greater diversity in the range of religious associations introducing 'new' deities. The chronological approach helps illustrate known trends in the nomenclature of associations as well as in their self-representation. For example, although religious associations of orgeones feature prominently in the epigraphic record of the $4^{\text {th }} \mathrm{c} . \mathrm{BC}$, there is a noticeable decline in the use of the term in the $3^{\text {rd }} \mathrm{c} . \mathrm{BC}$, whereas the $2^{\text {nd }} \mathrm{c} . \mathrm{BC}$ shows a limited revival in its use. By examining the structure as well as the social and ethnic composition of the groups, S. shows that religious associations in Athens usually consist of citizens. In addition, their internal organization displays a close resemblance to Athenian institutions, with the orgeones of the $4^{\text {th }} \mathrm{c}$. BC also providing a model that foreigners could adapt to their own needs. According to S., foreigners usually lie behind the introduction of 'new' deities, something that can indeed be clearly seen in some instances. For example, in 333/2 BC merchants from Kition were granted permission to found a sanctuary of Aphrodite in Piraeus (IG II $^{3} 337$ ). However, as S. notes, foreigners do not figure prominently as members of religious associations in Athens and Piraeus. To explain this absence, S. postulates that the epigraphic record, as it now stands, represents a "third phase" in the development of the membership of the religious associations, which was now open to locals - i.e. Athenian citizens - (p. 49); on p. 107 we learn - ex silentio - that "the first two generations seem to be anepigraphic".

5 Ch. 3 focusses exclusively on Delos. Religious associations are mainly attested in the $2^{\text {nd }}$ and $1^{\text {st }} \mathrm{c} . \mathrm{BC}$, a period that for the most part coincides with the Second Athenian Occupation. Delos, thanks to the rich archaeological record, presents an ideal case for the contextualization of the epigraphic material. Here too the discussion revolves around 'new' deities and their sanctuaries, and in particular around associations linked to specific locales: (1) the three Serapieia (A, B and C), (2) the 'Sanctuary of the Syrian 
Gods', (3) the sanctuaries on Mt Kynthos, (4) the 'Synagogue', and (5) the clubhouse of the Poseidoniasts of Berytos. Given that Delos constitutes one of the two special casestudies of the book, with Delian material also informing the discussion in the three remaining chapters $(4,5$ and 6$)$, it is unfortunate that $\mathrm{S}$. has missed the fact that Serapieion C was a public sanctuary already from ca. $180 \mathrm{BC}$. Claims to the contrary, i.e. that it was a private sanctuary that the Athenians tried to control (p. 67-68), cannot stand up to scrutiny. Likewise, it should come as no surprise that dedications from the sanctuary of the Syrian Gods do not feature in the inventories of the hieropoioi (i.e. lists compiled by civic officials and not the "managers" of the sanctuaries) (p. 68): this sanctuary became public only after $120 \mathrm{BC}$, at which date an architectural uplift began to be undertaken, and therefore it cannot feature in the inventories, all of which antedate this period.

6 Of the remaining three thematic chapters, ch. 4 addresses the question of the internal organization of associations, namely their membership and leadership. S. focusses on both 'new' (e.g. Serapis, Bendis, Sabazios, the Mother of Gods, Syrian deities, etc.) and old deities (such as Dionysos) in an attempt to assess to what extent religious associations might have instigated changes in cultic practices and rituals. S. offers a comparative study of associations of Serapiastai across the Aegean, arguing that Egyptian features of this cult "were transformed or sometimes even newly invented in Greece" (p. 92). Moreover, the membership is mostly Greek, and when the inscriptions allow insights into the social background of members, citizens seem to outnumber metics, at least as far as Athens is concerned.

7 Drawing on architectural remains as well as on epigraphically attested architectural terms, chapter 5 constitutes an intriguing study of sanctuaries and meeting-rooms of associations. The material is classified in four broad categories: (1) funerary sites, (2) temples and sanctuaries, (3) dining halls in temples and sanctuaries, and lastly (4) free-standing assembly-rooms. As S. argues, associations could own their own sanctuaries (e.g. the orgeones of Bendis in Piraeus; the Metroon of the orgeones of the Mother of Gods in Piraeus) or meet in civic sanctuaries (e.g. the Asklepiastai in Athens); they could possess their own assembly-rooms (e.g. the Iobakchoi in Athens; the boukoloi in Pergamon; the Poseidoniasts in Delos; the mystai of Dionysos in Melos) as well as their own burial grounds (notably apparent on Rhodes and Kos). It is not only difficult to safely identify meeting-places of associations in the archaeological record, it is equally difficult, as S. points out, to observe any general architectural patterns, especially when it comes to the architecture of free-standing assembly-rooms. Notwithstanding these difficulties, a basic pattern is discernible: some associations of 'new' deities are located in the newer parts of cities (p. 138-139).

Chapter 6 deals with the 'institutionalization' of associations. To underline the complexity of this question, S. again presents three case-studies (Athens, Delos and Rhodes). More specifically, she examines to what extent, if any, associations developed completely new institutional forms; adopted pre-existing civic structures which in turn may have been vested with a new meaning; or constituted a blend of the above (p. 141). She points out that each case presents a different reality. Unlike Delos where associations did not model themselves on pre-existing civic structures, in Athens, associations appropriated pre-existing terminology and practices, and at the same time tailored these to their needs. S. argues that this proved a successful strategy for attracting members. In the case of Rhodes, on the other hand, she claims that the 
nature of the material is not sufficient to draw a comprehensive picture, though she affirms that religious associations in Rhodes "lacked specifically Rhodian characteristics" (p. 158).

9 The underlying thesis, especially in the case of Athens, is that by the Hellenistic period, cults of 'new' deities which had been introduced already in the Classical period by foreigners, were accommodated by religious associations that attracted mostly locals (i.e. citizens) as members. In adopting local institutional forms, religious associations facilitated the assimilation of 'new' deities into local host societies, thus allowing these cults to thrive. Although this model may occasionally be able to provide an explanation for the discrepancy between the date of the introduction of a new cult and the first attestation of a religious association centered around this cult (e.g. Bendis in Athens), it nonetheless fails to satisfactorily address the realities present in a number of cities. For example, it is impossible to apply this model to cases such as the Serapiastai in Rhamnous, Thasos or Keos, all groups consisting of citizens. In the case of Rhamnous, one fails to see how a group consisting probably of soldiers stationed in this fort-deme in Attica, honoring the efforts of a benefactor to build a sanctuary for the cult of Serapis and Isis (Demos Rhamnountos II 59, lines 13-15), could correspond to a thirdgeneration group that was established decades before it became epigraphically visible. Furthermore, in adopting this model, S. falls into the trap of interpreting the evidence wholly through a process of assimilation. For example, in the case of the sanctuary of the Mother of Gods in Piraeus, S. envisages that an association of thiasotai ( $I G \mathrm{II}^{2} 1273$ ) and a koinon ton orgeonon (IG II ${ }^{2} 1316$ ) "seem to have amalgamated ... under the title orgeones" (p. 94-95). An alternative would be to view the sanctuary of the Mother of Gods in Piraeus in the $3^{\text {rd }} \mathrm{c}$. BC as a fertile ground for local competition between groups formed by individuals of different political or social statuses.

10 Although S. is to be praised for the speedy publication of her PhD thesis, numerous factual errors concerning the material, which allow wider misinterpretations to develop, could have been avoided by the author and her editors. To illustrate this, one may mention only a few cases from the three cities extensively discussed in the book: Delos, Athens, and Rhodes. Concerning Delos, the therapeutai of the Egyptian deities and the therapeutai of the Oriental deities are occasionally treated indistinguishably as one group (p. 69). The fact that individuals made dedications or contributions to both sanctuaries does not support a claim that one group of therapeutai worshipped both deities. In another instance, S. affirms that the Poseidoniasts of Berytos honoured Antiochus VIII (p. 68, n. 97); the honours, however, are bestowed by the demos of Laodikeia in Phoinike (Berytos) and not the association, though members of the association originated from the same city. In light of the analysis of the Dionysiastai in Piraeus in chs. 2 and $4-$ one of the few instances where the epigraphic evidence can shed light on the archaeological remains - it is surprising to read that "the group owned or rented a naos" (p. 45). A closer reading of the epigraphic dossier would have excluded the second possibility (of a lease). Despite the fact that several inscriptions are cited throughout the volume, a careful reading of the texts would have clarified several misunderstandings. In the case of the Poseidoniasts on Delos and the Iobakchoi in Athens, the statements (p. 49 and p. 66 respectively) that the inscriptions do not contain much information about the associations' religious life are unfounded. On the one hand, as IDélos 1520 informs us, the Poseidoniasts celebrated annually the Posideia (lines 32, 38) and participated in the festival of Apollo (lines 50-51), and Trümper has emphasised that the design of the clubhouse of the group accommodated a sacred 
space. ${ }^{3}$ The Iobakchoi, on the other hand, celebrated annually the stibas, the main religious festival of the association as shown by Jaccottet. ${ }^{4}$ Regrettably, both of the relevant recent studies on these groups have not been consulted. Furthermore, it is hard to explain why the Androklidai of Ephesos are averred to be "quite prominent" on Delos (p. 65), since no inscription from Delos attests to this group. Turning to Rhodes, it should be clarified that the decree of the Sabaziastai was found rebuilt in a later wall of a funerary complex in the western necropolis in the area of Kizil-Tepe (not "in the south-east necropolis in the area of Kyzil-Tepe", p. 113). In light of the inscriptions, the funerary complex should in all likelihood be identified with a familial burial ground. ${ }^{5}$ Lastly, the names of some associations (IG XII 1, 36 and IG XII 1, 159) do not provide any support to the claim that Athena Lindia was the "patron deity" of associations in Rhodes (p. 157).

In conclusion, with its focus on so-called 'new' deities, the book presents us only with part of the whole picture: religious associations in the post-classical polis did not exclusively center on imported cults. Material related to traditional gods is omitted (again, with the exception of Dionysos). Yet, if discussed, this would have painted a much more vivid picture, that of co-existence between associations devoted to different gods: for instance, we only hear about the Serapiastai on Thasos and nothing about the Poseidoniastai (IG XII Suppl. 366), despite the fact that both associations are roughly contemporary and epigraphically visible in the western part of the city, close to the 'Port au Char'. Furthermore, one would have expected to find a more holistic approach to the case-studies: for instance, it is surprising to see that the Competaliastai or similar groups in Delos, mostly related to the Italian population, are not adduced. It can also be added that the study leaves out groups whose activities could qualify them as religious, especially associations formed as a result of a testament or an endowment for the commemoration of family members. ${ }^{6}$ Although these groups did not pay respect to 'new' deities in S.'s sense of this phrase, by founding cults for deceased family members, they nevertheless considerably enriched the religious makeup of their local communities. In light of the rich material available, and beyond the often inscrutable issue of newness, there are still fascinating questions to be asked about religious associations, such as concerning their processes of formation, their diverse activities, the interplay between groups, etc. All in all, a more fully informed, thorough, and balanced account of the multifaceted aspects of religious associations remains to be written.

\section{NOTES}

1. Two volumes of the De Gruyter series have already been published: J.S. KLOPPENBORG and R.S. Ascough, Greco-Roman Associations: Texts, Translations, and Commentary. I. Attica, Central Greece, Macedonia, Thrace, Berlin/Boston, 2011; P.A. HARLAND, Greco-Roman Associations: Texts, Translations and Commentary. II. North Coast of the Black Sea, Asia Minor, Berlin/Boston, 2014. For the Copenhagen Associations Project see http://copenhagenassociations.saxo.ku.dk.

2. .P. FOUCART, Des Associations religieuses chez les Grecs: thiases, éranes, orgéons, Paris, 1873. 
3. .M. TRÜMPER, "Where the non-Delians met in Delos. The meeting-places of foreign associations and ethnic communities in late Hellenistic Delos", in O.M. VAN NIJF and R. ALSTON (eds.), Political Culture in the Greek City after the Classical Age, Leuven, 2011, p. 49-100.

4. .A.-F. JACCOTTET, "Integriert Andersartigkeit: Die Rolle der dionysischen Vereine", in R. SCHLESIER (ed.), A Different God? Dionysos and Ancient Polytheism, Berlin/Boston, 2011, p. 413-431.

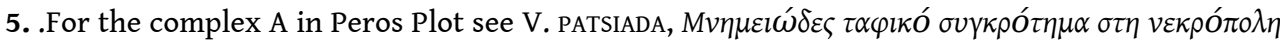

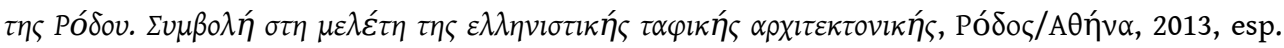
p. 211, n. 587 and p. 240, n. 715.

6. .See recently J.-M. CARBon and V. PiRenNe-Delforge, "Priests and Cult Personnel in Three Hellenistic Families", in M. HOSTER and A. KLÖCKNER (eds.), Cities and Priests. Cult personnel in Asia Minor and the Aegean islands from the Hellenistic to the Imperial period, Berlin/Boston, 2013, p. 65-119.

\section{AUTHORS}

\section{STELLA SKALTSA}

University of Copenhagen 